\title{
Experience of thrombotic microangiopathy unresponsive to therapeutic apheresis
}

\author{
Hilmi Erdem Sümbül1®, Onur Taktakoğlu²๑ \\ ${ }^{1}$ Department of Internal Medicine, Adana Numune Training and Research Hospital, Adana, Turkey \\ ${ }^{2}$ Department of Internal Medicine, Altınkoza Hospital, Adana, Turkey
}

DOI: $10.18621 /$ eurj.389830

Received: February 3, 2018; Accepted: June 1, 2018; Published Online: June 30, 2018

\section{Dear Editor,}

T hrombotic thrombocytopenic purpura (TTP) is a rare disease of unknown etiology characterized by severe thrombocytopenia, microangiopathic hemolytic anemia, fever, renal, neurologic and rarely cardiac involvement [1]. All cases of microangiopathic hemolytic anemia with thrombocytopenia should be considered as TTP and the treatment must be initiated immediately until the contrary is proved $[1,2]$.

A 48-year-old female patient with the history of diabetes mellitus and hypertension, immunosuppressive drugs user caused by vasculitis, was admitted to our clinic with vasculitis attack. Reference values are summarized in Table 1. Twentyfour hour urine protein was detected as $8 \mathrm{~g} /$ day. Renal biopsy findings were consistent with thrombotic microangiopathy. Pulse steroid (1g/day) was administered for 3 days and then $1 \mathrm{mg} / \mathrm{kg}$ methylprednisolone was continued. Cyclophosphamide $500 \mathrm{mg} / \mathrm{m}^{2}$ was applied because of persistent pancytopenia. Peripheral blood smear revealed blister cells, rare normoblasts and schistocytes. Direct Coombs test was negative. TTP was considered because the patient presented both microangiopathic hemolytic anemia with thrombocytopenia. Cyclophosphamide $500 \mathrm{mg} / \mathrm{m}^{2}$ was administered again because of totally 37 times unsuccessful therapeutic apheresis therapy and other signs of systemic vasculitis. Rituximab $1000 \mathrm{mg}$ was applied on the on the first and fifteenth days because the low platelets count, refractory microangiopathic hemolytic anemia. Pancytopenia had benefits (Figure 1), proteinuria level decreased to $885 \mathrm{mg} /$ day, the other systemic vasculitis signs (polyneuropathy, pretibial edema) were regressed and the patient was discharged in a healthy condition.

Plasma exchange procedure show a significant effect in treatment of TTP; all adult patients met the diagnostic criteria should be applied plasma exchange [3-5]. Plasma exchange may be effective in immunosuppressive treatment-resistant cases. According to the McDonald et al.'s study [5] in London University, rituximab therapy may be more effective in cases of high active ADAMST13 IgG antibodies study then low active ADAMST13 antibodies. It is clear that effective doses, location and maintenance of rituximab therapy should be studied in terms of TTP. All cases of microangiopathic hemolytic anemia with thrombocytopenia should be considered as TTP and the treatment must be initiated immediately like plasmapheresis, steroid, cyclophosphamide, rituximab etc. Even if rituximab is not considered as a first-choice treatment, yet it is a

Address for correspondence: Hilmi Erdem Sümbül, MD., Adana Numune Training and Research Hospital, Department of Internal Medicine, Adana, Turkey

E-mail: erdemsumbul@gmail.com 
Table 1. The reference values on admission

\begin{tabular}{ccc}
\hline WBC: $1,87 \mu \mathrm{l}$ & Hemoglobin:8.2 gr/dl & Hematocrit: $24.6 \%$ \\
Neutrophil: $78.6 \%(1.47 \mu \mathrm{l})$ & MCV: $80 \mathrm{fl}$ & RDW: $16.2 \%$ \\
Lymphoccyte: $11.6 \%(0.22 \mu \mathrm{l})$ & Eosinophil: $0.3 \%$ & Platelet: $205 \mu \mathrm{l}$ \\
LDH: $219 \mathrm{U} / \mathrm{L}$ & Sodium: $134 \mathrm{mmol} / \mathrm{L}$ & BUN:33 $\mathrm{mg} / \mathrm{dl}$ \\
CRP: $6.54 \mathrm{mg} / \mathrm{dl}$ & Potassium: $5.1 \mathrm{mmol} / \mathrm{L}$ & Creatinine: $1.04 \mathrm{mg} / \mathrm{dl}$ \\
Sedimentation: 35 & ALT: $15 \mathrm{U} / \mathrm{L}$ & Total protein: $4.9 \mathrm{~g} / \mathrm{dl}$ \\
Rheumatoid factor: $118 \mathrm{I} / \mathrm{ml}$ & AST:20 U/L & Albumin: $2.8 \mathrm{~g} / \mathrm{dl}$ \\
\hline
\end{tabular}

promising drug in treatment of TTP.

\section{Authorship declaration}

All authors listed meet the authorship criteria according to the latest guidelines of the International Committee of Medical Journal Editors, and all authors are in agreement with the manuscript.

\section{Conflict of interest}

The authors declared that there are no potential conflicts of interest with respect to the research, authorship, and/or publication of this article.

\section{REFERENCES}

[1] George JN. How I treat patients with thrombotic thrombocytopenic purpura:2010. Blood 2010;116:4060-9.

[2] Kremer Hovinga JA, Vesely SK, Terrell DR, Lammle B, George JN. Survival and relapse in patient with thrombotic thrombocytopenic purpura. Blood 2010;115:1500-11.

[3] George JN, Woodson RD, Kiss JE, Kojouri K, Vesely SK. Rituximab therapy for thrombotic thrombocytopenic purpura: a proposed study of the Transfusion Medicine/Hemostasis Clinical Trials Network with a systematic review of rituximab therapy for immune-mediated disorders. J Clin Apher 2006;21:49-56.

[4] Ling HT, Field JJ, Blinder MA. Sustained response with rituximab in patients with thrombotic thrombocytopenic purpura: a report of 13 cases and review of the literature. Am J Hematol 2009;84:418-21.

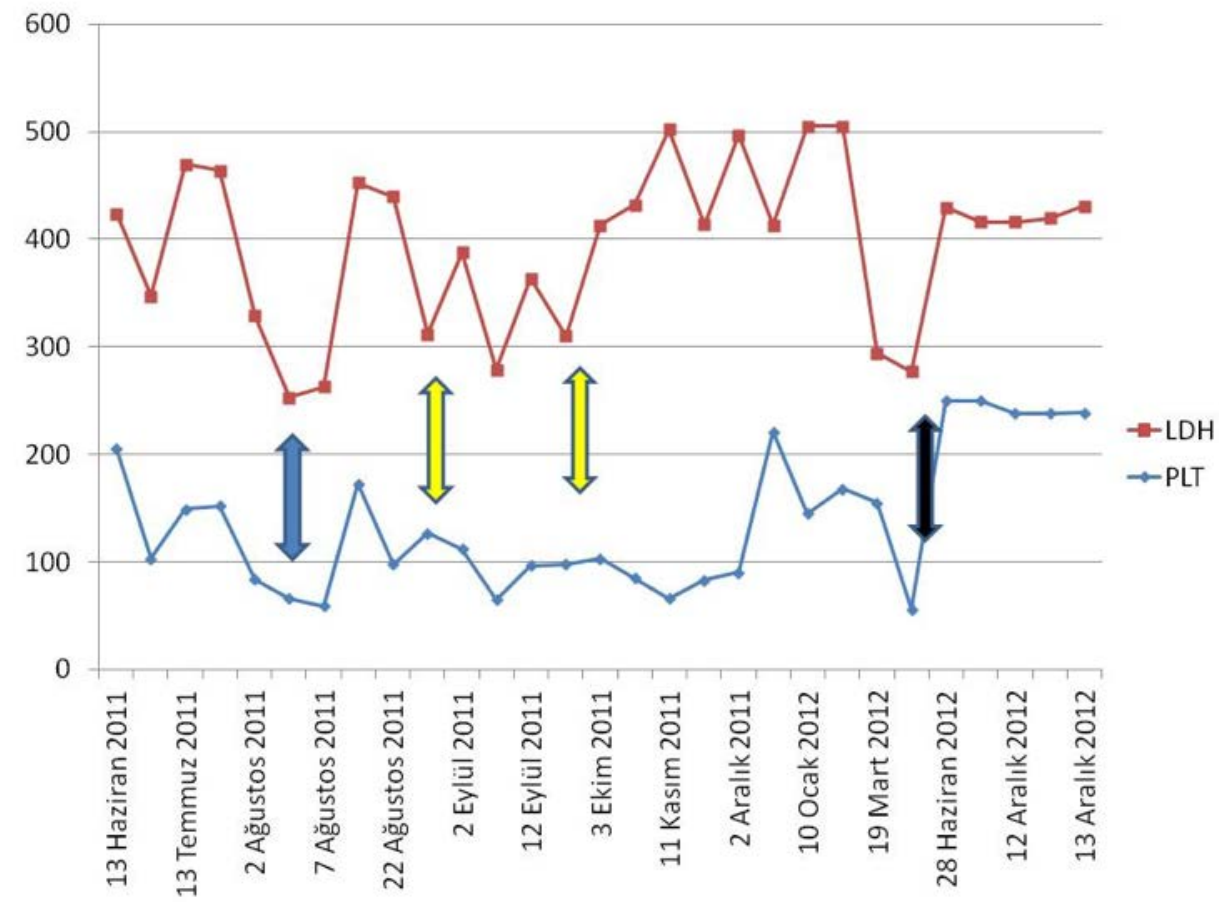

Figure 1. Course of LDH and PLT. Blue arrow indicates start of plasmapheresis program. Yellow arrow indicates cyclophosphamide therapies and black arrow for Rituximab. 
[5] McDonald V, Manns K, Mackie IJ, Machin SJ, Scully MA. thrombotic thrombocytopenic purpura. J Thromb Haemost 2010;8:1201Rituximab pharmakonetics during the management of acute idiopathic 